\title{
SENI KALIGRAFI: PERAN DAN KONTRIBUSINYA TERHADAP PERADABAN ISLAM
}

\author{
Laily Fitriani \\ Fakultas Humaniora dan Budaya Universitas Islam Negeri Maulana Malik \\ Ibrahim Malang. Jalan. Gajayana No: 50 Malang. Telp. 081333480529. e-mail: \\ fitrianilaily@yahoo.co.id
}

\begin{abstract}
Calligraphy, one of the Islamic arts, has gotten a great attention in Muslim community. Basically, calligraphy is artistic writings (khat) taken from Al Quran and it is named based on the place: Makki, Madani, Anbari and Baghdadi. By the time, names of (khat) shown, seems like Khufi, Mutsallats, Mudawwar, and some other types of writing. Calligraphy has a big role in developing Islamic civilization in the world. The influence of Islamic power expantions, Arabitation, the role of the King and social elites give motivation and facilitate the development of calligraphy and influent the development of science especially in Abbasiyah period. After the Abbasiyah period, the existence of calligraphy still was existing, developing and showing the phenomenal calligrafers like Ibnu

Muqlah.
\end{abstract}

Key words: Calligraphy arts, Islamic civilizationKey words: Calligraphy arts, Islamic civilization

Kaligrafi merupakan salah satu kesenian Islam yang mendapat perhatian besar dari kalangan umat Islam. Pada dasarnya kaligrafi adalah seni tulisan indah (khat) yang diambil dari al Qur'an dan diberi nama sesuai dengan tempat (munculnya); Makki, Madani, Anbari dan Baghdadi. Seiring dengan perkembangan waktu, tampil beberapa nama (khat) seperti, khat Khufi, mutsallat, mudawwar dan seterusnya. Seni kaligrafi mempunyai peran yang besar dalam perkembangan peradaban Islam di dunia. Pengaruh dari ekspansi kekuatan Islam, perluasan Arab, peran raja dan masyarakat elit memberikan motivasi dan mempermudah perkembangan seni kaligrafi dan mempengaruhi perkambangan keilmuan khususnya pada masa daulah Abbasiyah. Setelah masa daulah Abbasiyah keberadaan kaligrafi masih tetap eksis, berkembang, bahkan muncul beberapa ahli kaligrafi seperti Ibnu Muqlah.

Kata kunci : seni kaligrafi, peradaban Islam.

\section{Pendahuluan}

Seni adalah produk aktivitas yang dilakukan secara sadar, bertujuan untuk mendapatkan atau mencapai estetika, dan sekaligus berfungsi sebagai salah satu jalan atau cara untuk menerjemahkan simbol-simbol. Kualitas simbol-simbol dan estetika tersebut dipengaruhi oleh sublimasi antara harmoni, kontras, frekuensi, 
ritme serta intensitas dalam proses kelahiran seni. Karena itu, seni seringkali berkonotasi estetika atau keindahan.

Islam, atau tepatnya kebudayaan Islam-seperti dikatakan Ismail al Faruqimemandang keindahan sebagai nilai tempat bergantungnya seluruh validitas Islam, yang terpancar melalui nilai-nilai keindahan absolut al Quran. “Al Quran Maha Mulia, tidak ada yang melebihi otoritas al Quran selain Allah sebagai pemberi sumber-Nya". Al Faruqi selanjutnya mengisyaratkan, estetika dalam Islam adalah sublimasi bukti keilahian, yaitu i'jaz (kualitas) al Quran tidak dapat ditiru atau ditandingi, baik dalam hal sastra, komposisi, irama, keindahan, balaghah, kesempurnaan gaya serta kekuatan dalam menampilkan makna. Dalam konsep Islam, Allah adalah pusat dari nilai-nilai estetika ini.

Kaligrafi adalah salah satu karya kesenian Islam yang paling penting. Kaligrafi Islam yang muncul di dunia Arab merupakan perkembangan seni menulis indah dalam huruf Arab yang disebut khat. Definisi tersebut sebenarnya persis sama dengan pengertian etimologis kata kaligrafi dari kata Yunani kaligraphia (menulis indah). Dalam perkembangannya, huruf Arab yang menjadi obyek seni khat berkembang sesuai dengan perkembangan tempat dimana tempat asal seni khat berada. Demikian pada abad ke-10, misalnya, gaya kufi merupakan awal perkembangan khat yang tadinya agak kaku menjadi semakin lentur dan ornamental meskipun tetap angular. Kemudian berkembang pula bentuk khat yang bersifat kursif (miring) yang diwujudkan dalam seni yang disebut sulus, naskhi, raiham, riqa dan tauqi. Pada fase berikutnya gaya riqa dan tauqi tidak tampak lagi penggunaannya. (Ambary, 1998: 181-184).

Kaligrafi Islam adalah pengejawantahan visual dari kristalisasi realitasrealitas spiritual (al haqa'iq) yang terkandung di dalam wahyu Islam. Kaligrafi datang untuk menduduki posisi khusus yang sangat istimewa dalam Islam sehingga dapat disebut sebagai leluhur seni visual Islam tradisional dan memiliki jejak yang sangat istimewa dalam peradaban Islam. (Nasr, 1993: 28-29).

Munculnya al khat al Arabi dengan bentuk yang baik dan indah sangat penting pada masa Islam, dikarenakan al khat adalah seni asli dan di dalamnya terdapat ruh peradaban dan falsafah Islam. (Jaudi, 1998: 170). 
Dengan demikian, kaligrafi menjadi salah satu seni tulisan yang berkembang hingga kini, dan memiliki peranan penting dalam perkembangan agama Islam di penjuru dunia.

\section{Timbulnya Tulisan Arab}

Huruf atau tulisan adalah sebagai salah satu alat untuk menyatakan apa yang ada di dalam pikiran manusia. Ketika orang belum lagi mengenal alat-alat komunikasi modern seperti radio, marconi, telefon dan sebagainya, huruf adalah alat penghubung dan pengantar yang penting dalam hidup kemasyarakatan dan pengetahuan. (Israr, 1978: 9).

Fase pertama dari silsilah khat Arab ialah khat Mesir kuno, kemudian terpecah ke khat Finiqi, menjadi al Rami dan Musnad dengan macam-macamnya seperti al Shafawi, al Tsamudi dan al Lihyani di utara jazirah Arab dan al Himyari di selatan Jazirah Arabia. Terdapat perbedaan pendapat para rawi Arab dan peneliti dari bangsa asing tentang silsilah khat ini. Peneliti bangsa asing berpendapat bahwa dari al khat al Arami timbul al khat al Nabathi dan al Suryani (al Iskandari, 1961: 34).

Pada awal abad ketujuh Masehi, terjadi sedikit perkembangan penulisan di kalangan masyarakat Jazirah Arabia. Tulisan sederhana (belum sempurna) telah ada, seperti dibuktikan oleh temuan arkeologis (prasasti pada batu, pilar, dan seterusnya) di jazirah. Selain itu, sisa-sisa paleografis (tulisan pada material seperti papyrus dan kertas kulit) tertentu membuktikan bahwa orang Arab zaman itu mempunyai pengetahuan tentang seni tulis (Far, 1998: 391).

\section{Kedudukan Kaligrafi Arab}

Secara etimologi, kata "kaligrafi" berasal dari bahasa Yunani kaligraphia atau kaligraphos. Kallos berarti indah dan grapho berarti tulisan. Dengan demikian, kaligrafi mempunyai dua unsur, yakni tulisan (aksara) dan keindahan (nilai estetis).

Dalam bahasa Arab, kaligrafi disebut khat, yang berarti "dasar garis", "coretan pena", atau "tulisan tangan". Bentuk kata kerjanya adalah khatta yang berarti kataba (menulis) atau rasama (menggambar). Bahasa Arab mengistilahkan 
kaligrafi dengan kata khat (tulisan atau garis), yang ditujukan pada tulisan yang indah (al-kitabah al-jamilah atau al-khat al-jamil).

Dari segi terminologi, secara gamlang dikemukakan oleh Syaikh Syamsudin al Afkani (ahli kaligrafi) dalam kitabnya Irsyad al Qasid pada bab Hasyr al 'Ulum: "Khat adalah ilmu yang memperkenalkan bentuk huruf tunggal, penempatannya, dan cara merangkainya menjadi tulisan atau apa yang ditulis dalam baris-baris (tulisan), bagaimana cara menulisnya dan (menentukan mana) yang tidak perlu ditulis, mengubah ejaan yang perlu digubah dan bagaimana mengubahnya." Pengertian ini menjelaskan bahwa ilmu khat mencakup tata cara menulis huruf, menyusun dan merangkainya dalam komposisi tertentu demi mencapai keserasian (harmony) dan keseimbangan (equilibrium) yang dituntut setiap karya seni.

Dibandingkan dengan seni Islam yang lain, kaligrafi memperoleh kedudukan paling tinggi, dan merupakan ekspresi spirit Islam yang sangat khas. Oleh karena itu kaligrafi sering disebut sebagai "seninya seni Islam". Kualifikasi ini memang pantas karena kaligrafi mencerminkan kedalaman makna seni, yang esensinya berasal dari nilai dan konsep keimanan. Oleh sebab itu kaligrafi berpengaruh besar terhadap bentuk ekspresi seni yang lain atau dengan kata lain, terhadap ekspresi kultural secara umum. Hal ini diakui oleh para sarjana Barat yang banyak mengkaji seni Islam, seperti Martin Lings, Titus Burckhardt, Annemarie Schimmel, dan Thomas W. Arnold.

Keistimewaan kaligrafi dalam seni Islam terlihat terutama karena merupakan suatu bentuk "pengejawantahan" firman Allah SWT yang suci. Disamping itu, kaligrafi merupakan satu-satunya seni Islam yang dihasilkan murni oleh orang Islam sendiri, tidak seperti jenis seni Islam lain (seperti arsitektur, seni lukis dan ragam hias) yang banyak mendapat pengaruh dari seni dan seniman non-muslim. Tidak mengherankan jika sepanjang sejarah, penghargaan kaum muslim terhadap kaligrafi jauh lebih tinggi dibandingkan dengan jenis seni yang lain (AR, 2002: 290-292).

\section{Perkembangan Kaligrafi Arab}

\section{Masa Rasulullah dan Al Khulafa Ar Rasyidun}


Sebelum kedatangan Islam, bangsa Arab kurang terbiasa membaca dan menulis. Mereka lebih menyukai tradisi menghafal. Syair, nama silsilah, transaksi, atau perjanjian disampaikan dari mulut ke mulut tanpa dicatat. Hanya sedikit kalangan tertentu, seperti kalangan bangsawan Arab, yang menguasai keterampilan membaca dan menulis. Sampai pada masa awal Islam, yakni zaman Rasulullah SAW dan al Khulafa ar Rasyidun (Khalifah Abu Bakar as Siddiq, Umar bin Khattab, Usman bin Affan, dan Ali bin Abi Thalib; 632-661), corak kaligrafi masih kuno dan mengambil nama yang dinisbahkan kepada tempat tulisan dipakai, seperti Makki (tulisan Mekkah), Madani (tulisan Madinah), Hejazi (Hijaz), Anbari (Anbar), Hiri (Hirah), dan Kufi (kufah). Kufi merupakan yang paling dominan dan satu-satunya kaligrafi yang "dirajakan" untuk menulis mushaf (kodifikasi) al Quran sampai akhir kekuasaan al Khulafa ar Rasyidun.

Islam menghendaki orang Islam belajar menulis pada masa ini, sebagian sumber-sumber sejarah menyebutkan bahwa ada tujuh belas laki-laki dan tujuh wanita yang bisa menulis di Mekkah saat itu, dan sebagian sumber lain menyebutkan terdapat empat puluh dua orang penulis. Rasulullah SAW telah memerintahkan kepada para tawanan perang Badar untuk mengajari kaum muslimin menulis. Sehingga muncullah para sahabat yang ahli dalam menulis atau melakukan pencatatan ayat-ayat al Quran, seperti Ali bin Abi Thalib. Pada masa-masa awal Islam, yakni masa Rasulullah dan khulafaurrasyidin berkembang jenis khat al Hairi, al Anbari, al Kufi. Selanjutnya jenis khat ini pun berkembang pada masa Umawiyah (Jaudi, 1998: 33-34).

\section{Periode Umayyah (661-750)}

Memasuki zaman kekhalifahan Bani Umayyah (661-750), mulai timbul ketidakpuasan terhadap khatt Kufi yang dianggap terlalu kaku dan sulit digoreskan. Lalu mulailah pencarian bentuk lain yang dikembangkan dari gaya tulisan lembut (soft writing) non-Kufi, sehingga lahirlah banyak gaya. Jenis khat yang terpopuler diantaranya adalah Tumar, Jalil, Nisf, Sulus dan Sulusain. Khalifah pertama Bani Umayyah Mu'awiyah bin Abu Sufyan (661-680), adalah pelopor pendorong upaya pencarian bentuk baru kaligrafi tersebut (Armando, 2005: 47). 
Beberapa ragam kaligrafi awalnya dikembangkan berdasarkan nama kota tempat dikembangkannya tulisan. Dari berbagai karakter tulisan hanya ada tiga gaya utama yang berhubungan dengan tulisan yang dikenal di Makkah dan Madinah yaitu Mudawwar (bundar), Mutsallats (segitiga), dan Ti'im (kembar yang tersusun dari segitiga dan bundar). Dari tiga gaya tulisan ini pun, hanya dua yang diutamakan yaitu gaya kursif dan mudah ditulis yang disebut gaya Muqawwar berciri lembut, lentur dan gaya Mabsut berciri kaku dan terdiri goresan-goresan tebal (rectilinear). Dua gaya ini pun menyebabkan timbulnya pembentukan sejumlah gaya lain lagi diantaranya Mail (miring), Masyq (membesar) dan Naskh (inskriptif). Gaya Masyq dan Naskh terus berkembang, sedangkan Mail lambat laun ditinggalkan karena kalah oleh perkembangan Kufi. Perkembangan Kufi pun melahirkan beberapa variasi baik pada garis vertikal maupun horizontalnya, baik menyangkut huruf-huruf maupun hiasan ornamennya. Muncullah gaya Kufi Murabba' (lurus-lurus), Muwarraq (berdekorasi daun), Mudhaffar (dianyam), Mutarabith Mu'aqqad (terlilit berkaitan) dan lainnya. Demikian pula gaya kursif mengalami perkembangan luar biasa bahkan mengalahkan gaya Kufi, baik dalam hal keragaman gaya baru maupun penggunannya, dalam hal ini penyalinan al Quran, kitab-kitab agama, suratmenyurat dan lainnya.

Di antara kaligrafer Bani Umayyah yang termasyhur mengembangkan tulisan kursif adalah Qutbah al Muharrir. Ia menemukan empat tulisan yaitu Thumar, Jalil, Nisf, dan Tsuluts. Keempat tulisan ini saling melengkapi antara satu gaya dengan gaya lain sehingga menjadi lebih sempurna. Tulisan Thumar yang berciri tegak lurus ditulis dengan pena besar pada tumar-tumar (lembaran penuh, gulungan kulit atau kertas) yang tidak terpotong. Tulisan ini digunakan untuk komunikasi tertulis para khalifah kepada amir-amir dan penulisan dokumen resmi istana. Sedangkan tulisan Jalil yang berciri miring digunakan oleh masyarakat luas (Qalam, 2009: 1).

\section{Periode Abbasiyah (750-1258)}


Gerakan perkembangan seni khat telah mencapai masa keemasan pada masa ini disebabkan motivasi para khalifah dan pedana menteri Abbasiyah, sehingga bermunculan kelompok para kaligrafer yang jenius (Jaudi, 1998: 169).

Gaya dan teknik menulis kaligrafi semakin berkembang terlebih pada periode ini semakin banyak kaligrafer yang lahir, diantaranya Ad Dahhak Ibnu 'Ajlan yang hidup pada masa Khalifah Abu Abbas As Shaffah (750-754 M), dan Ishaq Ibnu Muhammad pada masa Khalifah al Manshur (754-775 M) dan al Mahdi (775-786 M). Ishaq memberi kontribusi yang besar bagi pengembangan tulisan Suluts dan Sulutsain dan mempopulerkan pemakaiannya. Kemudian kaligrafer lain yaitu Abu Yusuf as Sijzi yang belajar Jalil kepada Ishaq. Yusuf berhasil menciptakan huruf yang lebih halus dari sebelumnya.

Adapun kaligrafer periode Bani Abbasiyah yang tercatat sebagai nama besar adalah Ibnu Muqlah yang pada masa mudanya belajar kaligrafi kepada $\mathrm{Al}$ Ahwal al Muharrir. Ibnu Muqlah berjasa besar bagi pengembangan tulisan kursif karena penemuannya yang spektakuler tentang rumus-rumus geometrikal pada kaligrafi yang terdiri dari tiga unsur kesatuan baku dalam pembuatan huruf yang ia tawarkan yaitu: titik, huruf alif, dan lingkaran. Menurut Ibnu Muqlah, setiap huruf harus dibuat berdasarkan ketentuan ini dan disebut al-Khat al-Mansub (tulisan yang berstandar). Ia juga mempelopori pemakaian enam macam tulisan pokok (al-Aqlam as-Sittah) yaitu Suluts, Naskhi, Muhaqqaq, Raihani, Riqa', dan Tauqi' yang merupakan tulisan kursif. Tulisan Naskhi dan Suluts menjadi populer dipakai karena usaha Ibnu Muqlah yang akhirnya bisa menggeser dominasi khat Kufi.

Usaha Ibnu Muqlah pun dilanjutkan oleh murid-muridnya yang terkenal diantaranya Muhammad Ibnu As Simsimani dan Muhammad Ibnu Asad. Dari dua muridnya ini kemudian lahir kaligrafer bernama Ibnu Bawwab. Ibnu Bawwab mengembangkan lagi rumus yang sudah dirintis oleh Ibnu Muqlah yang dikenal dengan Al Mansub Al Faiq (huruf bersandar yang indah). Ia mempunyai perhatian besar terhadap perbaikan khatt Naskhi dan Muhaqqaq secara radikal. Namun karya-karyanya hanya sedikit yang tersisa hingga sekarang yaitu sebuah al Quran dan fragmen duniawi saja. 
Pada masa berikutnya muncul Yaqut al Musta'simi yang memperkenalkan metode baru dalam penulisan kaligrafi secara lebih lembut dan halus lagi terhadap enam gaya pokok yang masyhur itu. Yaqut adalah kaligrafer besar di masa akhir Daulah Abbasiyah hingga runtuhnya dinasti ini pada tahun 1258 M karena serbuan tentara Mongol.

Pemakaian kaligrafi pada masa Daulah Abbasiyah menunjukkan keberagaman yang sangat nyata, jauh bila dibandingkan dengan masa Umayyah. Para kaligrafer Daulah Abbasiyah sangat ambisius menggali penemuan-penemuan baru atau mendeformasi corak-corak yang tengah berkembang. Karya-karya kaligrafi lebih dominan dipakai sebagai ornamen dan arsitektur oleh Bani Abbasiyah daripada Bani Umayyah yang hanya mendominasi unsur ornamen

floral dan geometrik yang mendapat pengaruh kebudayaan Hellenisme dan Sasania. (Qalam, wordpress).

\section{Periode Lanjut (Pasca Abbasiyah)}

Sementara itu di wilayah Islam bagian barat (Maghribi), yang mencakup negeri Arab dekat Mesir, termasuk Andalusia (Spanyol), pada abad pertengahan berkembang bentuk tulisan yang disebut khatt Maghribi atau Kufi Barat, terdiri atas cabang khatt Qairawani, Andalusi, Fasi dan Sudani. Disini, telah dikembangkan pula Sulus Andalusi dan Naskhi Andalusi.

Selanjutnya, pertumbuhan kaligrafi masuk ke tahap konsolidasi dan penghalusan untuk menghasilkan karya masterpiece di zaman kerajaan Islam Persia. Seperti Ilkhaniyah (abad ke-13), Timuriyah (abad ke-15) dan Safawiyah (1502-1736), dan beberapa dinasti lain seperti Mamluk Mesir dan Suriah (12501517), Usmani Turki (Kerajaan Ottoman; abad ke-14-20) sampai kerajaan Islam Mughal India (abad ke-15-16) dan Afghanistan. Di masa ini lahir karya besar yang menunjukkan puncak kreasi agung seniman kaligrafi sekaligus menjadi lambang semangat Islam.

Pada masa ini tumbuh gaya tulisan seperti Farisi Ta'liq, dan Nasta'liq, Gubar, Jali dan Anjeh Ta'liq, Sikasteh, Sikasteh Ta'liq, Tahriri, Gubari Ta'liq, Diwani dan Diwani Jali (Humayuni), Gulzar, Tugra, dan Zulf I Arus. Khusus di India muncul khatt-khatt Behari, Kufi Herati, Naskhi India dan Sulus India. Tokoh 
kaligrafi kenamaan di masa ini antara lain adalah Yahya al Jamali (Ilkhaniyah), Umar Aqta (Timuriyah), Mir Ali Tabrizi dan Imaduddin al Husaini (Safawiyah), Muhammad bin al Wahid (Mamluk), Hamdullah al Amaasi, Ahmad dan Hasyim Muhammad al Baghdadi (enam tersebut terakhir adalah Usmani Turki sampai Turki modern).

Sekarang, sebagian dari gaya yang semula berjumlah ratusan telah pupus. Kini tinggal beberapa gaya yang paling fungsional di dunia Islam, yaitu Naskhi, Sulus, Raihani, Diwani, Jali, Farisi, Riq'ah dan Kufi. Bahasa yang menggunakan kaligrafi Arab menurut catatan Dr. Muhammad Tahir Kurdi (penulis Mushaf Makkah al-Mukarramah dan pengarang kitab Tarikh al Khatt al 'Arabi) terdiri atas lima kelompok, yaitu kelompok bahasa Turki, kelompok bahasa Hindia (termasuk Pegon atau Melayu/Jawi), kelompok bahasa Persia, kelompok bahasa Afrika, dan yang kelima, khusus bahasa Arab itu sendiri.

Kaligrafi kontemporer yang banyak dimuat dalam aneka media terus dikembangkan dalam bentuk kategori tradisional, figural, ekspresionis, dan simbolis, acap kali mendobrak batas gaya terdahulu. Hadir pula istilah "pemberontakan" atau "memberontak" yang menimbulkan keinginan 'uzlah (memisahkan diri) dari bentuk baku dan klasik. Motif "pemberontakan" sering tampak: (1) dalam pengolahan huruf yang menolah anatomi kaidah khatt seperti yang dirumuskan oleh Ibnu Muqlah, sehingga jenis khattnya tidak mudah lagi diidentifikasi; dan (2) mempertahankan gagasan penggunaan khatt baku, namun menempatkannya dalam variasi pengolahan yang puspa ragam, sehingga sebuah karya "tidak hanya selesai pada huruf", tetapi huruf dikombinasikan lebih erat dengan latar belakangnya untuk alasan penyatuan (wahdah).

Di Indonesia, corak kontemporer seperti ini sering diistilahkan dengan kata "lukisan" kaligrafi untuk membedakannya dengan kaligrafi "murni" yang telah dibakukan sejak zaman Ibnu Muqlah. Baik corak kaligrafi murni maupun lukisan kaligrafi beriringan dan dianut oleh para khattat (penulis) dan seniman kaligrafi di Indonesia, yang menunjukkan apresiasi dan perhatiannya terhadap seni tersebut. (Armando, 2005: 48).

Di Indonesia sendiri gaya Kufi ini terdapat di berbagai makam kuno, terutama yang imported, tetapi lebih lazim lagi kaligrafi gaya naskh (naskhi). 
Pada kaligrafi makam, selain memuat petikan-petikan ayat, basmalah, syahadat atau shalawat Nabi, kerapkali memuat nama si wafat berikut tahun wafatnya. Bahkan ada yang memuat silsilah. Seni kaligrafi Islam Nusantara, selain pada makam atau nisan, juga terdapat pada media lain sepeti deluang (lokal), kertas (impor), lontar, kayu, logam, kaca dan bahan lainnya. Bahkan pada perkembangannya kemudian, karya kaligrafi juga muncul melalui media kaca atau kanvas, dan juga batik (Ambary, 1998: 45).

\section{Faktor-Faktor yang Menyebabkan Kaligrafi Berkembang Pesat}

Selain eratnya kaitan antara al Quran dan perkembangan gaya kaligrafi, ada beberapa faktor lain yang menyebabkan kaligrafi dapat berkembang pesat dan menyebar demikian merata di dunia Islam. Faktor tersebut mencakup tiga hal pokok: Pertama, pengaruh ekspansi kekuasaan Islam. Setidaknya ada tiga hal berkaitan dengan ekspansi kekuasaan Islam, yang setelah wafatnya Nabi Muhammad SAW segera meluas jauh ke luar jazirah Arabia. Tiga hal tersebut adalah urbanisasi besar-besaran ke wilayah baru, pertemuan budaya antara Islam dan budaya wilayah taklukan, dan proses arabisasi pada wilayah tersebut.

Pada masa Daulah Umayyah, wilayah taklukan Islam ke timur telah mencapai perbatasan Cina dan India, sementara ke barat mencapai wilayah tepian Atlantik. Penaklukan wilayah ini segera diikuti oleh pengaturan administrasinya. Pada tahun 50 H/670 M misalnya, Umayyah mendirikan kota Qairawan (di Tunisia sekarang), sebuah perkemahan permanen sebagai pertahanan. Pendirian kota seperti ini segera terjadi di berbagai wilayah taklukan lain pada abad berikutnya. Pada masa Umayyah misalnya, sebagai akibat perluasan wilayah taklukan, terjadilah mobilitas sosial dalam masyarakat Islam. Karenanya masyarakat Islam selama 50 tahun pertama dikenal sebagai masyarakat yang sangat dinamis, secara sosial maupun geografis. Orang Arab yang berasal dari Jazirah Arabia menjadi komunitas yang paling banyak berpindah. Mereka berurbanisasi ke wilayah yang jauh, seperti Suriah, Mesir, Afrika utara, Mesopotamia atau ke Khurasan (Iran). 
Migrasi dan urbanisasi itu mau tak mau juga melibatkan kaum seniman dan budayawan muslim, memungkinkan terjadinya pertemuan budaya antara Arab (Islam) dan wilayah pusat kebudayaan seperti Mesopotamia, Bizantium, dan Persia. Hal ini berpengaruh besar bagi kekayaan dan kemajuan seni Islam. Satu hal yang tidak mungkin dikesampingkan dalam proses ini adalah arabisasi wilayah taklukan. Pada awal sejarah Islam, Daulah Umayyah merupakan pemerintahan yang menerapkan kebijakan administratifnya berdasarkan ide-ide kearaban. Ini mengakibatkan meluasnya pemakaian bahasa Arab dalam wilayah taklukan.

Proses yang didukung oleh pemerintahan selanjutnya ini membawa bahasa Arab bukan saja sebagai bahasa liturgis, namun juga sekaligus kultural. Bahasa Arab akhirnya menjadi bahasa akademik dan kesusastraan. Di pihak lain, huruf Arab pun kemudian menjadi huruf untuk bahasa non-Arab, seperti bahasa Parsi, Urdu, Turki dan Melayu (Jawi). Kedua fenomena terakhir, berkenaan dengan pemakaian bahasa dan huruf Arab yang membawa pengaruh kuat dalam perkembangan kaligrafi, memunculkan beragam gaya dan teknik penulisan. Bahkan tidak jarang wilayah yang berbeda memunculkan model huruf yang berbeda pula, karena pengaruh corak budaya lokal.

Kedua, peranan raja dan elit sosial. Pesatnya perkembangan kaligrafi Islam sangat erat kaitannya dengan dukungan dan fasilitas yang diberikan oleh raja dan kaun elite sosial, yang memungkinkan seniman muslim mengembangkan kreativitasnya. Dari catatan sejarah didapatkan banyak bukti tentang hal ini. Diceritakan bahwa gaya tulisan Tumar (lembaran halus daun pohon Tumar) diciptakan atas perintah langsung Khalifah Mu'awiyah (40 H/661 M-60 H/680 M). gaya ini kemudian menjadi tulisan resmi pemerintahan Daulah Umayyah. Pada masa Daulah Abbasiyah dan pemerintahan berikutnya, perhatian istimewa terhadap kaligrafi semakin kuat. Kitab al Fihrist karangan an Nadim (abad ke-10), sebuah karya monumental ensiklopedis yang pantas dijuluki rekaman peradaban dalam arti sesungguhnya, menunjukkan hal ini. An Nadim menyebutkan bahwa masa pemerintahan Khalifah Ma'mun (197 H/813 M-218 H/833 M) merupakan kulminasi perkembangan kaligrafi. Para penulis di masa itu aktif dalam memperindah huruf Arab. Dukungan pihak istana terhadap pertumbuhan kaligrafi 
terus berlanjut pada kurun berikutnya di berbagai wilayah dunia Islam. Beberapa sultan Daulah Usmani di Turki dikenal sebagai ahli kaligrafi. Mereka bahkan tak segan belajar kaligrafi kepada penulis istananya.

Kemudian pembukaan kota besar sebagai pusat pemerintahan dan kebudayaan Islam membawa pengaruh bagi tumbuhnya kaum elite tertentu di masyarakat. Ditunjang oleh berbagai pengaruh, baik pengaruh ekonomi (perdagangan) maupun kontak budaya, kaum elite sosial ini mempunyai perhatian yang cukup besar terhadap karya seni. Benda seni seperti keramik bertuliskan kaligrafi, misalnya, sangat disukai oleh kaum ini. Pada masa itu muncul pengrajin non-muslim berkebangsaan Yunani dan Koptik, serta terdapat pula pengaruh produksi benda seni dari Cina.

Ketiga, pengaruh perkembangan ilmu pengetahuan. Minat terhadap ilmu pengetahuan yang telah tumbuh sejak masa Daulah Umayyah mengalami perkembangan luar biasa pada masa berikutnya. Pada masa ini telah kertas telah ada yang dikenalkan oleh orang Arab dari Cina di Samarkand pada tahun 133 H/751 M. Seiring dengan munculnya kertas, maka berkembang pula kreasi manusia yang lebih leluasa. Pemakaian kertas segera meluas ke berbagai kota Islam dan merupakan salah satu sebab utama perkembangan tulisan kursif ornamental. Gaya kaligrafi yang telah ada sebelumnya seperti Tumar, Jalil, Nisf, dan Sulus yang betapa pun masih sangat sederhana, segera berkembang menjadi lebih halus, seperti Khafif as Sulus, Khafif as Sulusain, dan Ri'asi. Tak lama kemudian muncul gaya lain yang dikenal sebagai enam gaya pokok kaligrafi awal (al-Aqlam as-Sittah) yaitu Sulus, Naskhi, Muhaqqaq, Raihani, Riqa', dan Tauqi'. (AR, 2002: 293-295).

Seiring dengan berkembangnya zaman, aneka gaya kaligrafi juga mengalami perkembangan dengan munculnya berbagai pola dan bentuk serta media. Hal ini ditandai dengan munculnya trend-trend dalam kaligrafi kontemporer di dunia muslim, seperti tradisional, figural, ekspresionis, simbolis dan abstraksionis murni (Far, 1998: 402).

\section{Peran dan Kontribusi Seni Kaligrafi terhadap Peradaban Islam}


Konstribusi kaligrafi terhadap peradaban Islam dapat kita lihat dari beberapa aspek, yaitu:

1. Aspek religius, yaitu dakwah Islam melalui seni kaligrafi.

Kaligrafi al Quran menyuarakan wahyu Islam dan sekaligus menggambarkan tanggapan orang-orang Islam terhadap pesan Ilahi. Titik-titik yang ditulis oleh menciptakan pola dasar surgawi tentang kaligrafi al Quran dan juga garis-garis serta kandungan-kandungan hukum alam yang tidak hanya membentuk ruang angkasa, namun juga ruang arsitektur Islam. (Nasr, 1993: 28).

Melalui penulisan dan pembacaan huruf-huruf, kata-kata, dan ayat-ayat ini, manusia merasakan bahwa kalimat-kalimat al Quran dalam bentuk kaligrafi bukan sekedar kalimat-kalimat yang memancarkan gagasan, namun juga memancarkan kekuatan dalam diri pembacanya.

2. Aspek etika, yaitu kesadaran ritual keberagamaan.

Melalui seni kaligrafi manusia dapat mengetahui hakekat yang maha kuasa. Nilai-nilai al Quran yang diaplikasikan oleh para kaligrafer dapat membawa para pembacanya memahami dan memaknai kehidupan sesuai dengan ayat-ayat yang tertulis dalam kaligrafi.

\section{Simpulan}

Dari paparan diatas, dapat disimpulkan bahwa seni kaligrafi memiliki konstribusi positif dalam penyebaran agama Islam di seluruh penjuru dunia. Seni ini merupakan salah satu seni yang sangat berharga dan dihormati oleh seluruh kaum muslimin. Kaligrafi yang merupakan "pengejawantahan" firman Allah SWT akan terus berkembang dengan beraneka model sebagai bentuk pengapresiasian umat Islam terhadap tulisan indah Arab, sehingga seni kaligrafi terus mengalami perkembangan dan tidak menutup kemungkinan akan memunculkan kaligraferkaligrafer handal sekelas Ibnu Muqlah pada masa Abbasiyah. 


\section{Daftar Pustaka}

Al-Iskandari, Ahmad, dan Mushthofa 'Anani. 1961. Al-Wasit Fi Al-Adab Al'Arabi Wa Tarikhihi. Misr: Dar al-Ma'arif.

Ambary, Hasan Muarif. 1998. Menemukan Peradaban Jejak Arkeologis dan Historis Islam Indonesia. Jakarta: Logos Wacana Ilmu.

Al-Faruqi, Isma'il $\mathrm{R}$ dan Lois Lamya al-Faruqi. 1998. Atlas Budaya Islam. Bandung: Mizan.

AR Sirojuddin, H D. 2002. "Lukisan Tembok, Kaligrafi, dan Arabes" dalam Ensiklopedi Tematis Dunia Islam. Jakarta: Ichtiar Baru van Hoeve.

Armando, Nina. 2005. Ensiklopedi Islam. Jakarta: Ichtiar Baru van Hoeve.

Israr, C. 1978. Sejarah Kesenian Islam Jilid 2. Jakarta: Bulan Bintang.

Jaudi, Muhammad Husain. 1998. Al-Fan al-'Araby al-Islami. Oman: Dar alMasirah.

Nasr, Seyyed Hossein. 1993. Spiritualitas Dan Seni Islam. Bandung: Mizan.

(http://hilyatulqalam.wordpress.com/2009/01/11/sejarah-perkembangan-kaligrafidi-indonesia/) diakses pada tanggal 01 Nopember 2009. 